\title{
Chemosensitivity based on pathologic complete response in very young patients ( $<35$ years) with ER- positive breast cancer: a large retrospective cohort study
}

Joohyun Woo

Ewha Womans University College of Medicine

Se Jeong Oh

Catholic University of Korea College of Medicine

Jeong-Yoon Song

Kyung Hee University Hospital at Gangdong

Byung Joo Chae

Sungkyunkwan University School of Medicine

Jung Eun Choi

Yeungnam University Hospital

Jeeyeon Lee

Kyungpook National University School of Medicine

Heung Kyu Park

Gachon University Gil Medical Center

Woosung Lim ( $\sim$ limw@ewha.ac.kr)

Ewha Womans University College of Medicine https://orcid.org/0000-0002-2863-9346

\section{Research article}

Keywords: Breast cancer, Young patients, Chemosensitivity, ER-positive, Pathologic complete response

Posted Date: July 23rd, 2020

DOI: https://doi.org/10.21203/rs.3.rs-44805/v1

License: (c) (1) This work is licensed under a Creative Commons Attribution 4.0 International License. Read Full License 


\section{Abstract \\ Background}

In estrogen receptor (ER)-positive breast cancer, young age is associated with poor prognosis. Several reports have suggested hormonal mechanism as the possible reason. Conversely, very young patients respond better to chemotherapy, and adjuvant chemotherapy is less effective in ER-positive tumors than in ER-negative tumors. The authors tried to evaluate the chemoinsensitivity of very young patients with ER-positive breast cancer excluding the effect of endocrine treatment to the extent possible.

\section{Methods}

We collected individual patient data from 1992 to 2013 from the Korean Breast Cancer Society (KBCS), and 1,049 ER-positive patients aged $<50$ years who had been treated with neoadjuvant chemotherapy were included for analysis. We compared the pathologic complete response (PCR) rate between patients aged < 35 years and those aged $35-49$ years.

\section{Results}

One hundred forty seven patients $(14.0 \%)$ aged $<35$ years and 901 patients $(86.0 \%)$ aged $35-49$ years were studied. Although most chracteristics of tumors were comparable in both groups, tumors with high Ki-67 expression were found in $49.4 \%$ of patients aged $<35$ years and in $32.7 \%$ of patients aged $35-49$ years $(P=$ 0.007). Breast conservation rates were not significantly different between the two groups $(44.2 \%$ vs. $46.8 \%, P$ $=0.30)$. $\mathrm{pCR}$ rates of both breasts and axilla were not significantly different between the two groups $(\mathrm{P}=$ $0.87)$.

\section{Conclusions}

Chemotherapy response based on PCR rates was not better in young patients ( $<35$ years) with ER-positive breast cancer than in older premenopausal patients with ER-positive breast cancer; however, the proportion of tumors with high $\mathrm{Ki}-67$ proliferative index was greater in the former.

\section{Trial registration:}

retrospectively registered

\section{Background}

The incidence of breast cancer in very young women aged $<35$ years is higher in Korea $(\sim 9.5 \%)$ than in Western countries $(<6 \%) .(1,2)$ Young age at diagnosis is associated with poor prognosis. When compared with older women, young women are at a higher risk of having poorly differentiated and highly proliferative 
breast cancer.(3) Tumors in young women more often showed higher S-phase fractions and abnormal p53 expression.(4) In addition, these women were at higher risk of having more positive lymph nodes and larger tumors.(5) Young women are typically diagnosed with more advanced disease, which can be attributed to delayed diagnosis owing to the expected low incidence in young women, lower sensitivity of mammography in dense breasts, pregnancy, and lactation.(6-8) Young women are at a significantly increased risk of dying after adjustment for known prognostic factors and expected mortality.(9)

Breast cancer is less ER-positive in younger women than in older women. It has been reported that the proportion of ER-positive tumor is $48-52 \%$ in young patients. $(3,4,10)$ Survival outcomes are significantly worse in young patients than in older patients with ER-positive tumors. However, the prognosis did not differ between young patients and older patients with ER-negative tumors.(11-13) Even if positive ER is a good prognostic factor, it would affect different age groups differently. Several reports have suggested endocrine mechanisms as the possible underlying reason. Worse outcomes of young patients with ER positive tumors would be incompletely explained by a lower chance of chemotherapy-induced amenorrhea and the resistance to tamoxifen in adjuvant treatment in ER-positive tumor. $(12,14)$

Conversely, it has been reported that adjuvant chemotherapy is less effective in ER-positive tumors than in ER-negative tumors. A trend towards an advantage for younger women under 35 years was observed.(15) In addition, the effect of age on response to chemotherapy according to the ER status has not been sufficiently assessed. Herein, the authors hypothesized that response to chemotherapy is a cause of poor prognosis in young women with ER-positive breast cancer and tried to evaluate the chemoresistance to and benefits from neoadjuvant chemotherapy in young patients with ER-positive breast cancer while excluding the effect of endocrine treatment as much as possible.

\section{Methods}

\section{Patient population}

In this study, all patients with primary breast cancer who received neoadjuvant chemotherapy followed by surgery between August, 1991 and November, 2013 were included for analysis. Patients with distant metastasis at diagnosis or unknown ER status and male patients were excluded (Figure 1). This study was approved by the institutional review board of the Ewha Clinical Trial Center at Ewha Womans University Medical Center, Korea.

\section{Retrospective Data Collection}

We collected individual patient data from the Korean Breast Cancer Society (KBCS). Korean Breast Cancer Registry (KBCR) is a collection of medical information relating to breast cancer patients. Nationwide, breast surgeons in a total of 102 general hospitals (41 university hospitals and 61 teaching hospitals) with 400 or more beds participate voluntarily in this registry since 1996.(14) Individual hospitals recruited new patients who were diagnosed with breast cancer by pathologic examination of breast tissue and sent prospectively collected data of these patients to KBCS in the form of a filled-up recorded cancer registration sheet. In 2001, KBCS developed an online registration system, which made it more convenient for surgeons to enter patient 
enrollment data themselves. This web-based database has been managed by KBCS. The patients who were newly diagnosed as having breast cancer between 1992 and 1996, which is before the registration system was introduced, were recruited retrospectively. Data of these patients were collected from the database of each individual hospital and added to the KBCS database. This database comprises essential patient information, including unique registration number, the date of diagnosis and surgery, age at surgery, gender, the surgical method used, and clinical and pathologic tumor stage according the American Joint Committee on Cancer classification. It contains optional information, such as information on clinical and laboratory findings before surgery, tumor size, nodal status, histologic grade and type, Ki-67 proliferation index after surgery and before chemotherapy in case of neoadjuvant chemotherapy, and nuclear grade and biologic markers, including the expression status of estrogen receptor (ER), progesterone receptor (PR) and human epidermal growth factor receptor 2 (HER2). The goals of chemotherapy, such as neoadjuvant, adjuvant, or palliative therapy, and information about the administered chemotherapy regimen, radiotherapy, and endocrine therapy are recorded as treatment details. Even currently, these items are prospectively recorded starting from diagnosis of breast cancer, and overall survival data and the cause of death have been updated consistently through the Korean Central Cancer Registry, Ministry of Health and Welfare, Korea. Enrolled patients in this registry had given written informed consent for data collection at diagnosis. The database was reviewed to identify patients who met the criteria.

\section{Variables}

Patients with no evidence of invasive residual tumor in breast or nodes irrespective of noninvasive components in the final surgical specimen were considered to have obtained pCR. Because not all cases could be confirmed histologically for lymph node metastasis before neoadjuvant chemotherapy was started, in these cases, total PCR and only-breast PCR statuses could be obtained by pathologic stage after surgery.

The status of ER, PR, and HER2 was classified as negative or positive through immunohistochemistry (IHC) in individual hospitals. For the classification of the HER2 status, if the IHC result was a score of $2+$, which was considered as equivocal, the result of FISH was reflected. TNM (tumor size, node status, and metastasis) stages determined before 2010 were re-classified according to the seventh edition of the TNM classification. The Ki-67 index was categorized into low and high according to the $2013 \mathrm{St}$. Gallen consensus(16). If the Ki67 index information was not available, histologic grade III was considered as highly proliferative tumor and histologic grades I or II were considered as low proliferative tumors. The chemotherapy regimen administered was classified as anthracycline-based or not. Younger patient group comprised patients below the age of 35 years and the older group comprised those aged 35-49 years.

\section{Statistical Analysis}

SPSS software version 20 (SPSS, Chicago, IL, USA) was used for all statistical analyses. Basic data on the characteristics of study subject groups were compared and analyzed using Chi-squared tests. The mean values of the subgroups were compared with each other using independent sample t-tests (Student t-test) to examine statistical significance. The association between clinicopathologic parameters and pCR rate within each subgroup was evaluated using the Chi-squared test and univariate Cox regression analysis. 
Furthermore, multivariate Cox regression analysis was used to determine the independent prognostic value within the stratified cohorts. A p-value of $<0.05$ for a two-sided test was considered statistically significant.

\section{Results}

\section{Clinicopathological characteristics of the study population}

As authors expected, young patients aged $<35$ years were much fewer than older patients aged 35-49 years in both ER-positive and -negative groups (14.0\% and 16.8\%). The proportion of young patients was comparable in the two groups $(P=0.099)$.

Most baseline characteristics were comparable irrespective of age in each group (Table 1). However, in the ER-negative group, there were significantly more HER2-negative tumors in young patients than in older patients $(P=0.001)$. In addition, the proportion of patients with high proliferative index was higher in young patients in both ER-positive and -negative groups (35.4\% and 67.9\%); however, the proportion of patients with high proliferative index was smaller than that with low proliferative index in the ER-positive group irrespective of age. 
Table 1

Clinicopathological parameters.

\begin{tabular}{|c|c|c|c|c|c|c|}
\hline \multirow[t]{3}{*}{ Variables } & \multicolumn{3}{|l|}{$\begin{array}{l}\text { ER- } \\
\text { Positive }\end{array}$} & \multicolumn{3}{|l|}{ ER-Negative } \\
\hline & Age $<35$ & $\begin{array}{l}35 \leq \text { Age } \leq \\
50\end{array}$ & & Age $<35$ & $35 \leq$ Age $\leq 50$ & \\
\hline & $(N=147)$ & $(N=901)$ & $\begin{array}{l}\mathrm{P}- \\
\text { value }\end{array}$ & $(N=134)$ & $(N=663)$ & P-value \\
\hline \multicolumn{7}{|c|}{ Year of diagnosis } \\
\hline 1991-1995 & $1(0.7)$ & $3(0.3)$ & & $1(0.7)$ & $3(0.4)$ & \\
\hline $1996-2000$ & $4(2.7)$ & $3(0.3)$ & & $1(0.7)$ & $12(1.8)$ & \\
\hline $2001-2005$ & $24(16.3)$ & 111 (12.3) & & 25 (18.7) & $99(14.7)$ & \\
\hline $2006-2010$ & $90(61.2)$ & 557 (61.8) & & $75(56.0)$ & 415 (61.5) & \\
\hline $2011-2013$ & $28(19.0)$ & 227 (25.2) & & 32 (23.9) & 146 (21.6) & \\
\hline Histology & & & 0.696 & & & 0.786 \\
\hline Ductal & $140(95.2)$ & 846 (93.9) & & $128(95.5)$ & 645 (95.5) & \\
\hline Lobular & $3(2.0)$ & $30(3.3)$ & & $0(0.0)$ & $2(0.3)$ & \\
\hline Other & $1(0.7)$ & $5(0.6)$ & & $2(0.1)$ & $8(1.2)$ & \\
\hline Unknown & $3(2.0)$ & $20(2.2)$ & & $4(3.0)$ & $20(3.0)$ & \\
\hline PR & & & 0.379 & & & 0.616 \\
\hline Negative & $45(30.6)$ & $244(27.1)$ & & $115(85.8)$ & $590(87.4)$ & \\
\hline Positive & $102(69.4)$ & $656(72.8)$ & & $19(14.2)$ & 85 (12.6) & \\
\hline Unknown & $0(0.0)$ & $1(0.1)$ & & $0(0.0)$ & $0(0.0)$ & \\
\hline HER2 & & & 0.404 & & & 0.012 \\
\hline Negative & $106(73.6)$ & $674(75.6)$ & & 104 (77.6) & 429 (64.9) & \\
\hline Positive & $37(25.7)$ & $215(24.1)$ & & $29(21.6)$ & 218 (33.0) & \\
\hline Unknown & $4(2.7)$ & $12(1.3)$ & & $1(0.7)$ & $16(2.4)$ & \\
\hline $\begin{array}{l}\text { Clinical Tumor } \\
\text { size }\end{array}$ & & & 1.000 & & & 0.745 \\
\hline$\leq 2 \mathrm{~cm}$ & $3(2.0)$ & $20(2.2)$ & & $2(1.5)$ & $14(2.1)$ & \\
\hline$>2 \mathrm{~cm}$ & 49 (33.3) & 290 (32.2) & & $51(38.1)$ & 210 (31.7) & \\
\hline
\end{tabular}

NOTE: Data are presented as No. (\%) unless otherwise specified.

$E R$ estrogen receptor; $P R$ progesterone receptor; HER2 human epidermal growth factor receptor 2 


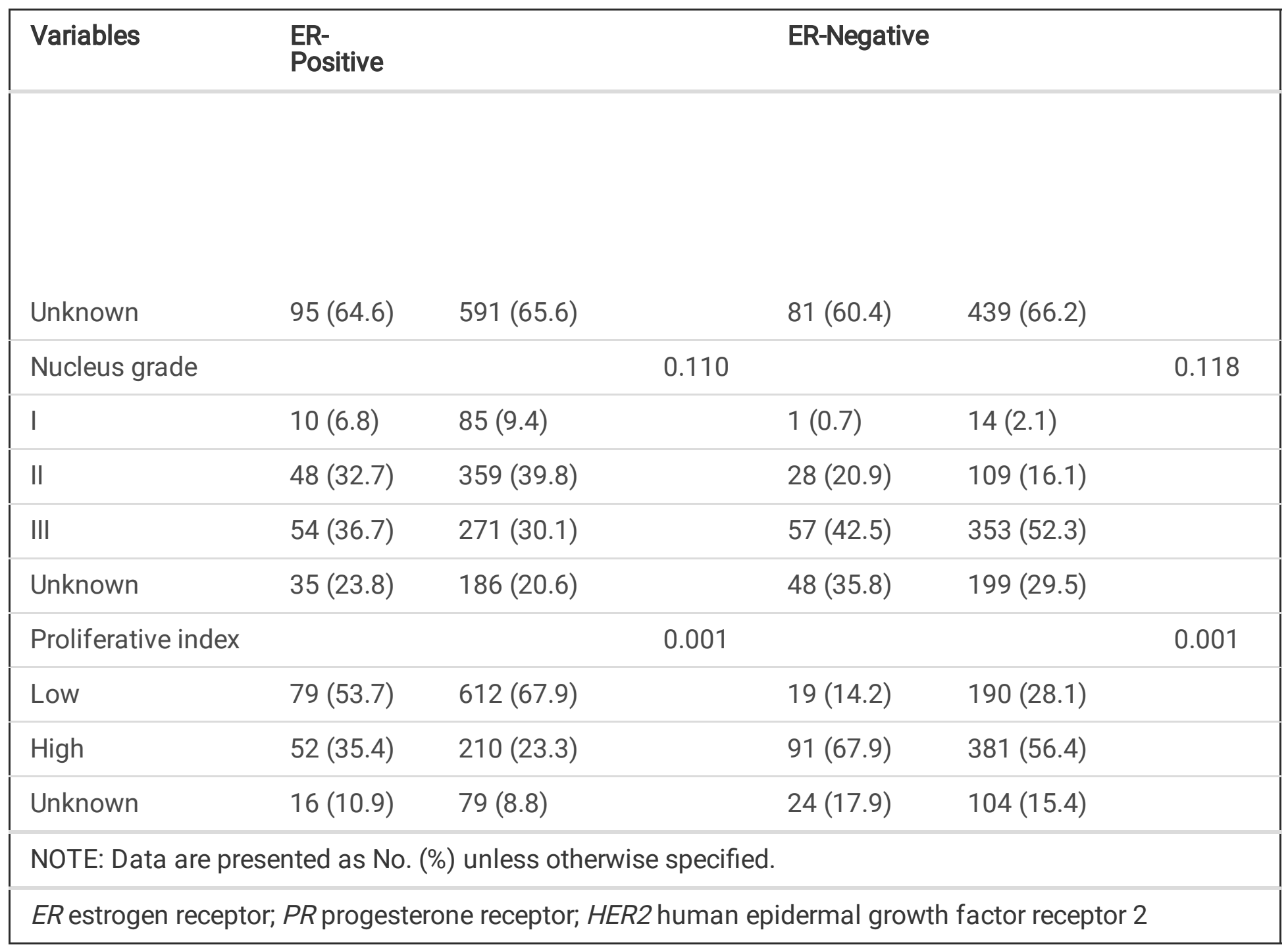

\section{Surgery and neoadjuvant chemotherapy}

More than $70 \%$ of patients in both young and older patients received neoadjuvant chemotherapy with anthracycline-based regimen. The proportion of patients who were administered concurrent trastuzumab as neoadjuvant treatment varied and were less than 9\% (Table 2). The proportion of HER2-positive patients treated with trastuzumab was comparable between young and older patients in both ER-positive and negative groups (Table 2). 
Table 2

Surgery and neoadjuvant chemotherapy

\begin{tabular}{|c|c|c|c|c|c|c|}
\hline & $\begin{array}{l}\text { ER- } \\
\text { Positive }\end{array}$ & & & $\begin{array}{l}\text { ER- } \\
\text { Negative }\end{array}$ & & \\
\hline & Age $<35$ & $\begin{array}{l}35 \leq \text { Age } \geq \\
50\end{array}$ & & Age $<35$ & $\begin{array}{l}35 \leq \text { Age } \geq \\
50\end{array}$ & \\
\hline Characteristic & $(\mathrm{N}=147)$ & $(\mathrm{N}=901)$ & $\begin{array}{l}\mathrm{P}- \\
\text { value }\end{array}$ & $(\mathrm{N}=134)$ & $(\mathrm{N}=675)$ & $\begin{array}{l}\mathrm{P}- \\
\text { value }\end{array}$ \\
\hline Breast surgery & & & 0.626 & & & 0.125 \\
\hline Conserving & $66(44.9)$ & $424(47.1)$ & & $74(55.2)$ & 318 (48.0) & \\
\hline Mastectomy & $81(55.1)$ & 477 (52.9) & & $60(44.8)$ & $345(52.0)$ & \\
\hline Axillary surgery & & & 0.561 & & & $0.005^{*}$ \\
\hline SLNB & $19(16.4)$ & $90(10.0)$ & & $27(20.1)$ & $69(10.4)$ & \\
\hline$S L N B \diamond A L N D$ & $43(26.0)$ & 269 (29.9) & & $27(20.1)$ & $174(26.2)$ & \\
\hline ALND & $85(56.2)$ & 540 (59.9) & & $80(59.7)$ & $420(63.3)$ & \\
\hline Unknown & $0(0.0)$ & $2(0.3)$ & & $0(0.0)$ & $0(0.0)$ & \\
\hline $\begin{array}{l}\text { Neoadjuvant } \\
\text { chemotherapy }\end{array}$ & & & 0.090 & & & 0.068 \\
\hline Anthracycline-based & $\begin{array}{l}111 \\
(75.5)\end{array}$ & 689 (76.5) & & 107 (79.9) & $504(74.7)$ & \\
\hline Others & $8(5.4)$ & $94(10.4)$ & & $9(6.7)$ & $82(12.1)$ & \\
\hline Unknown & $28(19.0)$ & $118(13.1)$ & & $18(13.4)$ & 89 (13.2) & \\
\hline
\end{tabular}


Table 3

Pathologic results after neoadjuvant chemotherapy and response to chemotherapy

\begin{tabular}{|c|c|c|c|c|c|c|}
\hline \multirow[t]{3}{*}{ Characteristic } & \multicolumn{3}{|l|}{$\begin{array}{l}\text { ER- } \\
\text { Positive }\end{array}$} & \multicolumn{3}{|l|}{$\begin{array}{l}\text { ER- } \\
\text { Negative }\end{array}$} \\
\hline & Age $<35$ & $\begin{array}{l}35 \leq \text { Age }< \\
50\end{array}$ & & Age $<35$ & $\begin{array}{l}35 \leq \text { Age }< \\
50\end{array}$ & \\
\hline & $(N=147)$ & $(\mathrm{N}=901)$ & $\begin{array}{l}\mathrm{P}- \\
\text { value }\end{array}$ & $(N=134)$ & $(N=675)$ & $\begin{array}{l}\mathrm{P} \text { - } \\
\text { value }\end{array}$ \\
\hline \multicolumn{7}{|l|}{ Postoperative T stage } \\
\hline урт0, урTis & $6(4.1)$ & $27(3.0)$ & 0.638 & $28(20.9)$ & $111(16.8)$ & 0.262 \\
\hline урT1-урT4 & $\begin{array}{l}141 \\
(95.9)\end{array}$ & $874(97.0)$ & & $106(79.1)$ & $564(83.2)$ & \\
\hline урТ1 & 47 (32.2) & 351 (39.1) & & $29(21.6)$ & $188(28.4)$ & \\
\hline урт2 & $69(47.3)$ & 348 (38.8) & & 45 (33.6) & $204(30.8)$ & \\
\hline урт3 & $22(15.1)$ & 158 (17.6) & & $23(17.2)$ & $94(14.2)$ & \\
\hline урТ4 & $2(1.4)$ & $14(1.3)$ & & $0(0)$ & $0(0)$ & \\
\hline \multicolumn{7}{|l|}{ Postoperative $\mathrm{N}$ stage } \\
\hline ypNO & $55(37.4)$ & 296 (32.9) & 0.515 & $77(57.5)$ & $301(45.4)$ & 0.016 \\
\hline ypN1-ypN3 & $92(62.6)$ & $604(67.0)$ & & $52(38.8)$ & $323(47.9)$ & \\
\hline \multicolumn{7}{|l|}{ Pathologic response } \\
\hline $\begin{array}{l}\text { Complete: breast and } \\
\text { axilla }\end{array}$ & $7(4.8)$ & $37(4.1)$ & 0.713 & $26(19.4)$ & $74(11.2)$ & 0.009 \\
\hline Complete: breast-only & $1(0.7)$ & $3(0.3)$ & 1.0 & $3(2.2)$ & $45(6.7)$ & 0.006 \\
\hline \multicolumn{7}{|c|}{ NOTE: Data are presented as No. (\%) unless otherwise specified. } \\
\hline$E R$ estrogen receptor & & & & & & \\
\hline
\end{tabular}

With regard to surgical treatment, the rate of breast-conserving surgery was not different between young and older patients in both ER-positive and -negative groups. Although the axillary lymph node status by pathological confirmation before neoadjuvant chemotherapy was uncertain, approximately $>80 \%$ patients in all groups received axillary lymph node dissection.

\section{Meaningful factor for $\mathrm{PCR}$}

In univariate analysis, pCR was achieved in young patients with nonpalpable tumors. It was also achieved in patients with ER- and PR-negative tumors and high proliferative index. Odds ratio of ER status was higher than that of age. When patients were stratified by their ER status, independent prognostic factors of $\mathrm{PCR}$ 
changed in young and older patients. Negative PR and high proliferative index were positive factors for PCR in the ER-positive group, and age $<35$ years was the only one in the ER-negative group. Patients with nonpalpable tumors had a higher tendency to achieve pCR in both groups (Table 4).

Table 4

Univariate and multivariate analysis for pathologic complete response

\begin{tabular}{|c|c|c|c|c|c|c|c|c|}
\hline \multirow[t]{4}{*}{ Variables } & \multicolumn{4}{|l|}{$\begin{array}{l}\text { ER- } \\
\text { Positive }\end{array}$} & \multicolumn{4}{|l|}{$\begin{array}{l}\text { ER- } \\
\text { Negative }\end{array}$} \\
\hline & \multicolumn{4}{|l|}{$\begin{array}{l}(N= \\
1048)\end{array}$} & \multicolumn{4}{|l|}{$(\mathrm{N}=809)$} \\
\hline & \multicolumn{2}{|l|}{ Univariate } & \multicolumn{2}{|l|}{ Multivariate } & \multicolumn{2}{|l|}{ Univariate } & \multicolumn{2}{|l|}{ Multivariate } \\
\hline & $\begin{array}{l}\text { OR }(95 \% \\
\mathrm{Cl})\end{array}$ & $\begin{array}{l}\mathrm{P} \text { - } \\
\text { value }\end{array}$ & OR $(95 \% \mathrm{Cl})$ & $\begin{array}{l}\mathrm{P}- \\
\text { value }\end{array}$ & $\begin{array}{l}\text { OR }(95 \% \\
\mathrm{Cl})\end{array}$ & $\begin{array}{l}\mathrm{P}- \\
\text { value }\end{array}$ & OR $(95 \% \mathrm{Cl})$ & $\begin{array}{l}\mathrm{P}- \\
\text { value }\end{array}$ \\
\hline Age $<35$ & $\begin{array}{l}1.17 \\
(0.51- \\
2.67)\end{array}$ & 0.71 & $\begin{array}{l}0.41(0.05- \\
3.19)\end{array}$ & 0.39 & $\begin{array}{l}1.92 \\
(1.17- \\
3.13)\end{array}$ & 0.01 & $\begin{array}{l}2.54(1.27- \\
5.08)\end{array}$ & 0.01 \\
\hline \multicolumn{9}{|l|}{$\begin{array}{l}\text { vs. } 35 \leq \\
\text { Age }<50\end{array}$} \\
\hline PR-negative & $\begin{array}{l}1.87 \\
(1.01- \\
3.47)\end{array}$ & 0.05 & $\begin{array}{l}2.00(0.68- \\
5.88)\end{array}$ & 0.21 & $\begin{array}{l}1.60 \\
(0.78- \\
3.27)\end{array}$ & 0.20 & $\begin{array}{l}5.45(1.26- \\
23.61)\end{array}$ & 0.02 \\
\hline \multicolumn{9}{|l|}{ vs. -positive } \\
\hline $\begin{array}{l}\text { HER2- } \\
\text { positive }\end{array}$ & $\begin{array}{l}0.67 \\
(0.33- \\
1.37)\end{array}$ & 0.28 & $\mathrm{NI}$ & & $\begin{array}{l}1.33 \\
(0.82- \\
2.16)\end{array}$ & 0.25 & $\mathrm{NI}$ & \\
\hline \multicolumn{9}{|l|}{ vs. -negative } \\
\hline $\begin{array}{l}\text { Proliferative } \\
\text { index }\end{array}$ & $\begin{array}{l}2.30 \\
(1.02- \\
5.20)\end{array}$ & 0.05 & $\begin{array}{l}3.45(1.17- \\
10.15)\end{array}$ & $0.03^{*}$ & $\begin{array}{l}1.00 \\
(0.58- \\
1.74)\end{array}$ & 0.99 & $\begin{array}{l}1.22(0.60- \\
2.46)\end{array}$ & 0.58 \\
\hline \multicolumn{9}{|l|}{$\begin{array}{l}\text { : high vs. } \\
\text { low }\end{array}$} \\
\hline Nonpalpable & $\begin{array}{l}3.28 \\
(0.93- \\
11.54)\end{array}$ & 0.06 & $\begin{array}{l}1.61(0.20- \\
13.16)\end{array}$ & 0.66 & $\begin{array}{l}2.27 \\
(0.93- \\
5.53)\end{array}$ & 0.07 & $\begin{array}{l}3.95(1.32- \\
11.8)\end{array}$ & 0.01 \\
\hline \multicolumn{9}{|l|}{ vs. palpable } \\
\hline
\end{tabular}

For multivariate analysis, the model was constructed on the basis of meaningful variables from univariate analysis, potential confounding variables in both ER-positive and -negative groups, and palpability of the tumor. Factors affecting pCR differed according to the ER status (Table 4). 
The $\mathrm{pCR}$ rate of young patients was higher than that of older patients in the ER-negative group but was comparable in the ER-positive group. Even after adjusting for confounding variables, young patients maintained the higher probability of PCR than older patients in ER-negative tumors. However, the pCR rate did not differ according to age in ER-positive tumors. In addition, the odds of pCR rate changed from greater than 1 into less than 1 after adjustment (Table 5).

Table 5

Change of odds ratio after adjustment according to ER status

\begin{tabular}{|c|c|c|c|c|}
\hline & \multicolumn{2}{|c|}{ pCR rate $(\%)$} & \multirow[t]{2}{*}{ OR $(95 \% \mathrm{Cl})$} & \multirow[t]{2}{*}{ PI-Adjusted OR (95\% Cl) } \\
\hline & Age $<35$ & $35 \leq$ Age $<50$ & & \\
\hline \multirow[t]{2}{*}{ ER-positive } & $(N=147)$ & $(\mathrm{N}=901)$ & & \\
\hline & 4.8 & 4.1 & $1.17(0.51-2.67)$ & $0.41(0.05-3.19)$ \\
\hline \multirow[t]{2}{*}{ ER-negative } & $(\mathrm{N}=134)$ & $(N=675)$ & & \\
\hline & 19.4 & 11.2 & $1.92(1.17-3.13)$ & $2.54(1.27-5.08)$ \\
\hline
\end{tabular}

\section{Discussion}

This large retrospective study showed the chemosensitivity of young patients aged $<35$ years having ERpositive breast cancer with minimal endocrine effect. When other confounding factors were controlled, young patients were not found to respond to chemotherapy better than older patients in the ER-positive group. Although there was no change in odds ratio in the ER-negative group after adjustment, it was notable that odds ratio changed in the ER-positive group, albeit not statistically significantly. In other words, there was no difference of chemosensitivity beween young and older patients in ER-positive group while chemosensitivity of young patients was better than that of older pateints in ER-negative group. This suggests that benefit of chemotherapy in young patients with ER-positive breast cancers cannot be big, relatively.

Neoadjuvant chemotherapy is generally performed in patients with locally advanced breast cancers Physicians tend to give patients with advanced disease more aggressive treatment because of their high tumor burden and increased risk of recurrence and death.(17) In addition, as chemotherapy is considered more effective in younger patients with poor prognosis and shorter disease-free survival regardless of the type of treatment, tumor size, grade or progesterone receptor status, these patients are administered neoadjuvant chemotherapy for breast-conserving surgery or a lower threshold when determining chemotherapy. ${ }^{(1,2,18)} \mathrm{A}$ large study of patients aged $<50$ years reported that among patients with lower risk disease, those who were not treated with adjuvant systemic therapy and were aged $<35$ years had the worst prognosis. This age-related trend was not seen in high-risk patients with a greater number of metastatic nodes or a larger primary tumor size.They suggested that young women with breast cancer should be regarded as high risk patients and be given adjuvant cytotoxic treatment on the basis of age alone.(9) This 
recommendation is under the assumption that young patients would respond better to cytotoxic treatment even in lower risk disease.(19) However, steroid hormone status was not considered in this analysis.(9)

The association of young age with response to chemotherapy has not been clearly defined, particularly according to ER status.(20) In this study, young age was not an independent predictor of response to chemotherapy in ER-positive tumors. Patient age of $<35$ years was found to be associated with pCR in ERnegative tumors but not in ER-positive tumors. Better response to chemotherapy was related to aggressiveness of tumors in ER-positive breast cancers. High proliferative index was an independent factor only in ER-positive tumors. Therefore, in ER-positive tumors, it is hard to expect that complete pathologic response would be achieved in low proliferative tumors, even though they developed in young patients. Conversely, Early Breast Cancer Trialists' Collaborative Group reported that adding adjuvant polychemotherapy to tamoxifen was associated with $7.6 \%$ of 5 -year survival gain in patients aged $<50$ years with ER-positive tumors.(21) The survival benefit of chemotherapy in young patients was greater than in older patients. However, because survival benefit may not come from a cytotoxic effect of chemotherapy and the criteria for age were different, response to polychemotherapy in young women cannot be interpreted clearly. Furthermore as tamoxifen is the only endocrine therapy, the endocrine effect of chemotherapy would play an important role in benefit of chemotherapy for patients less than 50 years with ER-positive tumors as in most other studies.

The evidence of the benefit of adding chemotherapy to endocrine therapy in hormone-responsive breast cancer of young women is not strong. $(22,23)$ A pooled analysis of patients aged $\leq 40$ years enrolled in EORTC trials showed that prolonged adjuvant CMF chemotherapy did not bring survival advantage to hormone receptor-positive patients compared with hormone receptor-negative patients.(23) Several studies suggest very good prognosis with optimal endocrine therapy alone, particularly in low-risk young patients. (24) Treatment advances with endocrine agents, such as ovarian function suppression or aromatase inhibitor, to overcome resistance to endocrine therapy in young breast cancer patients could improve patient outcomes without chemotherapy in young women with ER-positive breast cancers. $(25,26)$ Improvement of outcome in these patients is attributed to the endocrine effect. Particularly in ER-positive early breast cancer, the role of chemotherapy can be limited to endocrine effect, not cytotoxic effect. A STEPP analysis for patients with ERpositive tumors who received dose-intensive epirubicin and cyclophosphamide suggested a correlation between the achievement of ovarian function suppression and efficacy of chemotherapy despite no interaction of age and chemotherapy.(27)

The bigger reason for the less benefit in these patients may be that ER-positive breast tumors resist chemotherapy. This study showed that the effect of ER status was greater than the effect of age. Some reports explain that the lower frequency of receptor positivity in premenopausal women may account for their increased response to cytotoxic chemotherapy.(28) Low response to chemotherapy of ER-positive breast cancers can counteract the effect of age. Even in palliative setting, endocrine treatment is recommended first in ER-positive breast cancer patients without visceral crisis. In addition, resistance to chemotherapy of estrogen receptor-positive breast tumors can be explained by biologic factors. Cancer stem cells in the ERpositive cells escape the effect of doxorubicin treatment by the elevation of p53 expression.(29) More tumors in young women had abnormal expression of p53.(4) 
Predictive value for response to chemotherapy of young agein ER-positive breast cancers should be considered differently from that in ER-negative breast cancers. Most studies have focused on the endocrine effect of chemotherapy regarding the prognosis of young patients with ER-positive tumors. Although indirectly, this study shows the cytotoxic effect of chemotherapy in young patients with ER-positive tumors while excluding the endocrine effects as much as possible. Age was an important predictor of pCR in ERnegative tumors but not in ER-positive tumors in this study. In previous studies, it has been reported that young breast cancer patients had better response to chemotherapy than older breast cancer patients. ${ }^{(30)}$ However, this result does not take ER status into consideration even though the proportion of ER-positive tumors was significantly different between both groups. A recent German study by Loibl et al. also reported that $\mathrm{PCR}$ was significantly higher following neoadjuvant treatment in patients aged $<35$ years than in those aged over 35 years, and the outcomes were similar only for the triple-negative breast cancer subtype. The conventional perception that young women respond better to chemotherapy needs to be accepted as limited to ER-negative breast cancers.

In ER-positive tumors, the effect of endocrine therapy following adjuvant chemotherapy makes it difficult to determine the cytotoxic effect of chemotherapy only on the outcome unclear in an adjuvant setting. Conversely, in a neoadjuvant setting, low rate of complete response to neoadjuvant chemotherapy may suggest resistance to chemotherapy because neoadjuvant chemotherapy is an in vivo measure of chemosensitivity.(31) However, chemotherapy inevitably has an endocrine effect, and response to chemotherapy may have less impact on prognosis relatively in ER-positive tumors when compared to ERnegative tumors. This may be a cause of a weak relationship between PCR and outcome of ER-positive tumors when it is compared to ER-negative tumors.

In this study, there are some limitations because it is a retrospective cohort study using multicenter database. Even though TNM stage at diagnosis was recorded, the exact tumor size or axillary lymph node status before neoadjuvant chemotherapy was uncertain. Some patients did not receive fine needle aspiration or sentinel lymph node biopsy for axillary lymph nodes. Therefore, only patients with pathologic complete response were included. In addition, pCR indicates high tumor chemosensitivity and is a meaningful factor to investigate the relationship between response to chemotherapy and disease outcome.(32) In addition, the neoadjuvant chemotherapy regimen including trastuzumab administration was not the standard treatment during the study period. For HER2-positive tumors, this study does not reflect the current treatment.

In an adjuvant setting, only the cytotoxic effect of chemotherapy could not be compared between young and older patients with ER-positive tumors due to the effect of adjuvant endocrine therapy. Therefore, despite these limitations, this study suggests that young age alone is not an immediate factor in determining a chemotherapy escalation or neoadjuvant chemotherapy in ER-positive breast cancers. If other predictive factors for response to chemotherapy are not found, even increasing breast-conserving rate after neoadjuvant chemotherapy may be hard to expect As in ER-positive breast cancers, response to neoadjuvant chemotherapy was not correlated with long-term outcomes, and poor response to chemotherapy based on pCR would not mean survival benefit of chemotherapy.(33)

\section{Conclusions}


For improving overall survival young patients with advanced ER-positive tumors, more effective endocrine therapy would be considered first, and then, a specific chemotherapy regimen or combination of drugs to target a different biology of young women may be required.

\section{Last Of Abbreviation}

ER: Estrogen receptor; KBCS: Korean Breast Cancer Society; pCR: pathologic complete response; PR: progesterone receptor; HER2: Human epidermal growth factor receptor; IHC: Immunohistochemistry; TNM: Tumor size, node status, and metastasis

\section{Declarations}

\section{Ethics approval and consent to participate}

All procedures performed in studies involving human participants were in accordance with the ethical standards of the institutional review board of the Ewha Clinical Trial Center at Ewha Womans University and with the 1964 Helsinki declaration and its later amendments or comparable ethical standards. Informed consent was obtained from all individual participants included in the study.

\section{Consent for publication}

Not applicable

\section{Availability of data and materials}

The datasets during and/or analysed during the current study are available from the corresponding author on reasonable request.

\section{Competing of interests}

The authors declare that they have no competing interests.

\section{Funding}

Not applicable

\section{Authors' contributions}

Conception and design: WL, JW. Collection and assembly of data: JW, KBCS. Data analysis and interpretation: WL, JW. Provision of study material or patients: WL, SO, JS, BC, JC, JL, HP, KBCS. Manuscript writing: JW. Final approval of manuscript: All authors.

\section{Acknowledgments}

This article was supported by the Korean Breast Cancer Society. 


\section{References}

1. de la Rochefordiere A, Asselain B, Campana F, Scholl SM, Fenton J, Vilcoq JR, et al. Age as prognostic factor in premenopausal breast carcinoma. Lancet. 1993;341(8852):1039-43.

2. Chung M, Chang HR, Bland KI, Wanebo HJ. Younger women with breast carcinoma have a poorer prognosis than older women. Cancer. 1996;77(1):97-103.

3. Walker RA, Lees E, Webb MB, Dearing SJ. Breast carcinomas occurring in young women (< 35 years) are different. British journal of cancer. 1996;74(11):1796-800.

4. Gajdos C, Tartter PI, Bleiweiss IJ, Bodian C, Brower ST. Stage 0 to stage III breast cancer in young women. Journal of the American College of Surgeons. 2000;190(5):523-9.

5. Albain KS, Allred DC, Clark GM. Breast cancer outcome and predictors of outcome: are there age differentials? Journal of the National Cancer Institute Monographs. 1994(16):35-42.

6. Afzelius P, Zedeler K, Sommer H, Mouridsen HT, Blichert-Toft M. Patient's and doctor's delay in primary breast cancer. Prognostic implications. Acta oncologica. 1994;33(4):345-51.

7. Petrek JA. Breast cancer and pregnancy. Journal of the National Cancer Institute Monographs. 1994(16):113-21.

8. Max MH, Klamer TW. Breast cancer in 120 women under 35 years old. A 10-year community-wide survey. The American surgeon. 1984;50(1):23-5.

9. Kroman N, Jensen MB, Wohlfahrt J, Mouridsen HT, Andersen PK, Melbye M. Factors influencing the effect of age on prognosis in breast cancer: population based study. BMJ. 2000;320(7233):474-8.

10. Maggard MA, O'Connell JB, Lane KE, Liu JH, Etzioni DA, Ko CY. Do young breast cancer patients have worse outcomes? Journal of Surgical Research. 2003;113(1):109-13.

11. Han W, Kang SY. Relationship between age at diagnosis and outcome of premenopausal breast cancer: age less than 35 years is a reasonable cut-off for defining young age-onset breast cancer. Breast cancer research and treatment. 2010;119(1):193-200.

12. Goldhirsch A, Gelber RD, Yothers G, Gray RJ, Green S, Bryant J, et al. Adjuvant therapy for very young women with breast cancer: need for tailored treatments. Journal of the National Cancer Institute Monographs. 2001(30):44-51.

13. Aebi S, Gelber S, Castiglione-Gertsch M, Gelber RD, Collins J, Thurlimann B, et al. Is chemotherapy alone adequate for young women with oestrogen-receptor-positive breast cancer? Lancet. 2000;355(9218):1869-74.

14. Ahn SH, Son BH, Kim SW, Kim SI, Jeong J, Ko SS, et al. Poor outcome of hormone receptor-positive breast cancer at very young age is due to tamoxifen resistance: nationwide survival data in Korea-a report from the Korean Breast Cancer Society. Journal of clinical oncology : official journal of the American Society of Clinical Oncology. 2007;25(17):2360-8.

15. Gianni A, editor Five-year results of the randomized clinical trial comparing standard versus high-dose myeloablative chemotherapy in the adjuvant treatment of breast cancer with> 3 positive nodes $(\mathrm{LN}+)$. Proc Am Soc Clin Oncol; 2001. 
16. Goldhirsch A, Winer E, Coates A, Gelber R, Piccart-Gebhart M, Thürlimann B, et al. Personalizing the treatment of women with early breast cancer: highlights of the St Gallen International Expert Consensus on the Primary Therapy of Early Breast Cancer 2013. Annals of oncology. 2013;24(9):2206-23.

17. Colleoni M, Rotmensz N, Robertson C, Orlando L, Viale G, Renne G, et al. Very young women (<35 years) with operable breast cancer: features of disease at presentation. Annals of Oncology. 2002;13(2):273-9.

18. Albain KS, Allred DC, Clark GM. Breast cancer outcome and predictors of outcome: are there age differentials? Journal of the National Cancer Institute Monographs. 1993(16):35-42.

19. Goldhirsch A, Gelber RD, Yothers G, Gray RJ, Green S, Bryant J, et al. Adjuvant therapy for very young women with breast cancer: need for tailored treatments. JNCI Monographs. 2001;2001(30):44-51.

20. Cancello G, Montagna E. Treatment of breast cancer in young women: do we need more aggressive therapies? Journal of thoracic disease. 2013;5 Suppl 1(Suppl 1):S47-S54.

21. Group EBCTC. Effects of chemotherapy and hormonal therapy for early breast cancer on recurrence and 15-year survival: an overview of the randomised trials. The Lancet. 2005;365(9472):1687-717.

22. Suter MB, Pagani O. Should age impact breast cancer management in young women? Fine tuning of treatment guidelines. Ther Adv Med Oncol. 2018;10:1758835918776923-.

23. van der Hage JA, Mieog JS, van de Vijver MJ, van de Velde CJ. Efficacy of adjuvant chemotherapy according to hormone receptor status in young patients with breast cancer: a pooled analysis. Breast cancer research : BCR. 2007;9(5):R70.

24. Tevaarwerk AJ, Wang M, Zhao F, Fetting JH, Cella D, Wagner LI, et al. Phase III comparison of tamoxifen versus tamoxifen plus ovarian function suppression in premenopausal women with node-negative, hormone receptor-positive breast cancer (E-3193, INT-0142): a trial of the Eastern Cooperative Oncology Group. Journal of Clinical Oncology. 2014;32(35):3948.

25. Francis PA, Regan MM, Fleming GF, Láng I, Ciruelos E, Bellet M, et al. Adjuvant ovarian suppression in premenopausal breast cancer. New England Journal of Medicine. 2015;372(5):436-46.

26. Ademuyiwa FO, Groman A, Hong C-C, Miller A, Kumar S, Levine E, et al. Time-trends in survival in young women with breast cancer in a SEER population-based study. Breast cancer research and treatment. 2013;138(1):241-8.

27. Colleoni M, Sun Z, Martinelli G, Basser R, Coates A, Gelber R, et al. The effect of endocrine responsiveness on high-risk breast cancer treated with dose-intensive chemotherapy: results of International Breast Cancer Study Group Trial 15-95 after prolonged follow-up. Annals of oncology. 2009;20(8):1344-51.

28. Knight WA, Livingston RB, Gregory EJ, McGuire WL. Estrogen receptor as an independent prognostic factor for early recurrence in breast cancer. Cancer research. 1977;37(12):4669-71.

29. Ashour F, Awwad MH, Sharawy HEL, Kamal M. Estrogen receptor positive breast tumors resist chemotherapy by the overexpression of P53 in Cancer Stem Cells. J Egypt Natl Canc Inst. 2018;30(2):458.

30. Braud AC, Asselain B, Scholl S, De La Rochefordiere A, Palangie T, Dieras V, et al. Neoadjuvant chemotherapy in young breast cancer patients: correlation between response and relapse? European journal of cancer. 1999;35(3):392-7. 
31. Smith IE, Lipton L. Preoperative/neoadjuvant medical therapy for early breast cancer. Lancet Oncol. 2001;2(9):561-70.

32. Dawood S, Broglio K, Kau S-W, Islam R, Symmans WF, Buchholz TA, et al. Prognostic value of initial clinical disease stage after achieving pathological complete response. The oncologist. 2008;13(1):6-15.

33. van Mackelenbergh MT, Denkert C, Nekljudova V, Karn T, Schem C, Marmé F, et al. Outcome after neoadjuvant chemotherapy in estrogen receptor-positive and progesterone receptor-negative breast cancer patients: a pooled analysis of individual patient data from ten prospectively randomized controlled neoadjuvant trials. Breast cancer research and treatment. 2018;167(1):59-71.

\section{Figures}

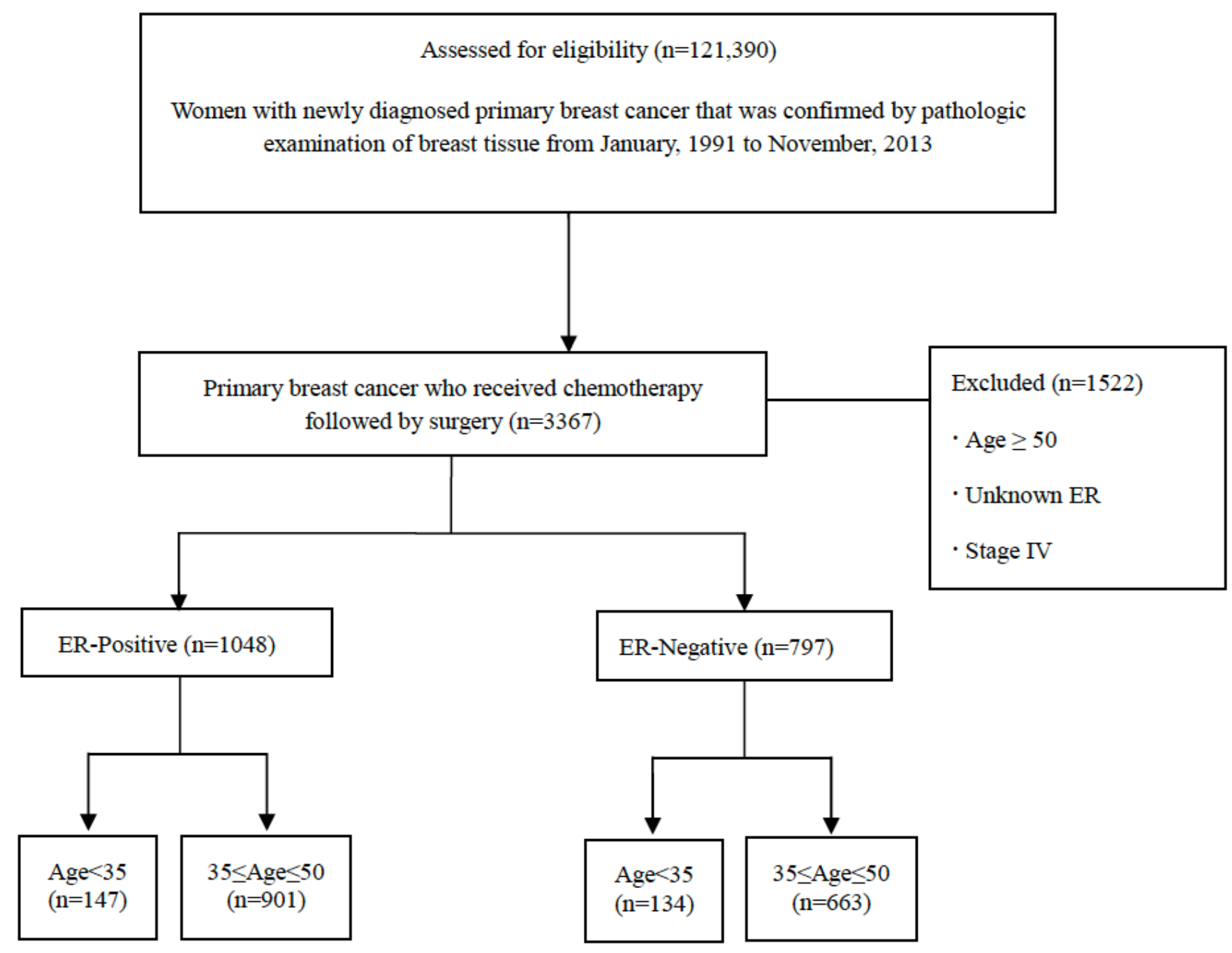

Figure 1

CONSORT diagram. 